International Journal of Life Sciences
Available online at www.sciencescholar.us
Vol. 4 No. 3, December 2020, pages: $50-58$
e-ISSN: 2550-6986, p-ISSN: 2550-6994
https://doi.org/10.29332/ijls.v4n3.538

\title{
Giving the Extract of Clove Leaves (Syzygium aromaticum L.) Fermented through Drinking Water against Growth of Kampong Chicken
}

\author{
Sosiawan Bulua, I Gede Mahardika ${ }^{b}$, I Made Nuriyasa ${ }^{c}$
}

Manuscript submitted: 9 September 2020, Manuscript revised: 18 October 2020, Accepted for publication: 27 November 2020

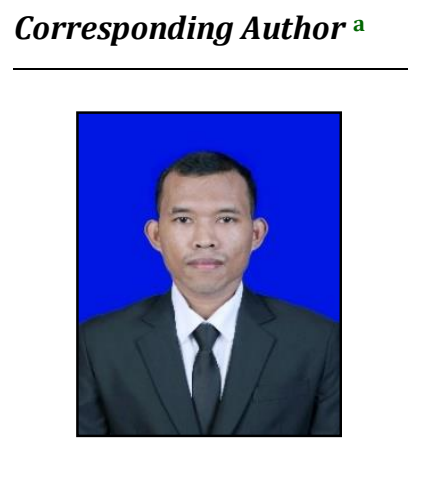

\section{Keywords}

digestibility;

fermented clove leaves;

free-range chicken;

growth;

microbes;

\begin{abstract}
This study aims to determine the microbial population, nutrient digestibility, and growth in native chickens fed fermented clove leaf extract through drinking water. The experimental design used was a completely randomized design (CRD) with four treatments and five replications, using three native chickens 2 weeks old in each unit. The treatments were drinking water without fermented clove leaf extract (P0), drinking water given 1\% fermented clove leaf extract (P1), drinking water was given $2 \%$ fermented clove leaf extract (P2), drinking water was given $3 \%$ fermented clove leaf extract (P3). The variables observed were microbial population, nutrient digestibility, and growth. The results showed that giving fermented clove leaf extract through drinking water in treatment $\mathrm{P} 1$ and $\mathrm{P} 2$ resulted in a significantly different increase in lactic acid bacteria $(\mathrm{P}<0.05)$ compared to the control and treatment $\mathrm{P} 1$ reduced pathogenic bacteria Escherichia Coli and Coliform significantly different $(\mathrm{P}<0$, 05) compared to control. Treatment $\mathrm{P} 2$ received a higher Total Plate Count (TPC) which was significantly different $(\mathrm{P}<0.05)$ compared to $\mathrm{P} 0, \mathrm{P} 1$, and $\mathrm{P} 3$. The digestibility values of dry matter, organic matter, crude protein, and digestible energy were significantly different in treatment $\mathrm{P} 1 \quad(\mathrm{P}<0.05)$ compared to the control.
\end{abstract}

International Journal of Life Sciences (C) 2020.

This is an open access article under the CC BY-NC-ND license (https://creativecommons.org/licenses/by-nc-nd/4.0/).

\section{Contents}

Abstract

1 Introduction

2 Materials and Methods.

3 Results and Discussions

\footnotetext{
${ }^{a}$ Master of Animal Science Study Program, Faculty of Animal Husbandry, Universitas Udayana, Denpasar, Indonesia

${ }^{b}$ Faculty of Animal Husbandry, Universitas Udayana, Denpasar, Indonesia

c Faculty of Animal Husbandry, Universitas Udayana, Denpasar, Indonesia
} 


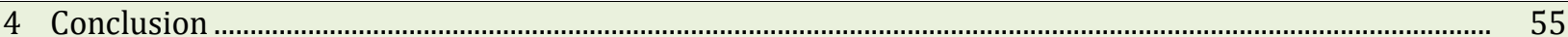

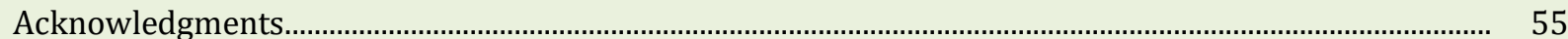

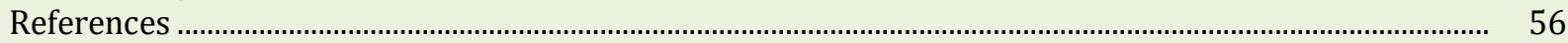

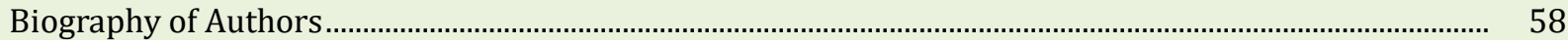

\section{Introduction}

Free-range chickens are chickens that have undergone a domestication process that has high adaptability characteristics to the environment in which they are raised and are known as types of poultry that have dual functions, namely laying hens and meat-producing chickens. Yaman (2013), states that the village chicken development efforts still face obstacles, namely traditional maintenance systems, low productivity, various genetic quality variations, high mortality rates, and feeding is not following the needs both quantity and quality. The productivity of native chickens is low so that the maintenance is relatively long, it is necessary to increase the productivity of native chickens so that they have good performance. This can be done by providing feed additives to improve the health and productivity of poultry (Wang et al., 2009; Huang et al., 2018; Dubey et al., 2007). The use of several feed additives such as hormones and antibiotics (antibiotic growth promoters or AGP) has been banned because they are related to current global issues in poultry farming, namely the safety of animal food from contaminants and residues that are harmful to consumers, certain bacterial resistance and environmental issues.

Research on herbal plants has been widely conducted and proven to be used as natural antibiotics as an appetite enhancer, kills pathogenic bacteria, reduces cholesterol levels in blood and meat, and provides optimal poultry productivity. Edi et al., (2018), stated that giving teak leaf extract as a feed additive in feed resulted in good productivity of laying hens. Kogoya et al. (2019), reported that the addition of Gedi leaf juice as an additive through drinking native chicken water increased body weight gain and ration conversion at a dose of up to $20 \mathrm{ml}$ / L which was called the most efficient. Zainuddin (2006), reported that medicinal herbs (jamu) for livestock mixed with EM-4 have been shown to increase poultry endurance, productivity, feed efficiency, meat carcass quality, meat aroma, and egg quality. Effective microorganism-4 (EM-4) is a mixture of beneficial microorganisms, mainly containing 90\% Lactobacillus sp, photosynthetic bacteria, Actinomycetes, fungi, and yeast (Arifin, 2003).

Another herbal plant that has potential as a natural antibiotic is the clove plant (Syzygium Aromaticum L.). Cloves have a large number of eugenol components (70-80\%) which have properties as stimulants, local anesthetics, carminatives, antiemetics, antiseptics, and antispasmodics (Nurdjannah, 2004). Clove leaves contain saponins, tannins, alkaloids, glycosides, and flavonoids (Ferdinanti, 2001). Flavonoid compounds are thought to be very useful in food because, in the form of phenolic compounds, these compounds are strong antioxidants. Flavonoid-rich foods are considered important for treating diseases, such as cancer and heart disease (Heinrich et al., 2010). The phytochemical compounds contained in it are flavonoids, saponins, tannins, and several other phenolic compounds that have antimicrobial activation (Bukar et al., 2010). Jufri (2010), states that giving clove powder into the broiler chicken ration up to a dose of $1.25 \%$ does not affect the performance of broiler chickens. Research on the use of fermented clove leaves with EM4 has not been widely carried out. Therefore, the researcher wanted to know the effect of fermented clove leaves through drinking water on the growth of native chickens.

\section{Materials and Methods}

\section{Kampong chicken}

The livestock used in this study were 60 unisex native chickens at the age of two weeks with a weight of $150.23 \mathrm{~g} \pm 2.29 \mathrm{~g}$.

Bulu, S., Mahardika, I. G., \& Nuriyasa, I. M. (2020). Giving the extract of clove leaves (Syzygium aromaticum L.) fermented through drinking water against growth of kampong chicken. International Journal of Life Sciences, 4(3), 50-58. https://doi.org/10.29332/ijls.v4n3.538 
Cages and equipment

The cage used in this research is the battery cage system of 20 boxes with a size of each box ( $\mathrm{L} \mathrm{X} \mathrm{W} \mathrm{x} \mathrm{H)} 60 \mathrm{~cm}$ x $50 \mathrm{~cm}$ x $40 \mathrm{~cm}$. The cage material used is BRC wire.

\section{Rations and drinking water}

Rations and drinking water were given ad libitum. The materials used in this research were yellow corn, fine bran, soybean meal, fish meal, coconut oil, premix, and CaCo3. The drinking water has given is water with a mixture of fermented clove leaf water extract at the level of $0 \%, 1 \%, 2 \%$, and $3 \%$. The variables observed in this study were the appearance of native chickens which included: initial body weight, final body weight, weight gain, ration consumption, drinking water consumption, and feed conversion ratio (FCR). Nutrient digestibility includes: dry matter digestibility, organic matter digestibility, protein digestibility, and efficient conversion of GE to DE. Lactic Acid Bacteria (LAB), Escherichia coli, Coliform, and Total Plate Count (TPC) Microbial Populations.

\section{Data analysis}

The data from this research will be analyzed using a variance. If the results were significantly different $(\mathrm{P}<0.05)$, it was continued with the Duncan multiple distance test (Steel \& Torrie, 1993).

\section{Results and Discussions}

The results showed that giving fermented clove leaf extract had a significant effect $(\mathrm{P}<0.05)$ on the total lactic acid bacteria (LAB). This condition is influenced by compounds found in clove leaves such as alkaloids, steroids, terpenoids, phenolics, saponins, flavonoids, and tannins. These compounds are antibacterial. Flavonoids are secondary metabolites from plants that have antibacterial, antifungal, anti-inflammatory properties (Khera \& Bhargava, 2013). P2 treatment with fermented clove leaf extract had the highest total lactic acid bacteria, an increase in the number of LAB microbes identified that giving fermented clove leaf extract had a significant effect on the growth and digestibility value of native chickens aged 2-10 weeks through drinking water. Sumardi \& Lengkana (2009), explain that lactic acid bacteria can control pathogenic bacteria, bacteria that are classified as Bacillus bacteria can produce a protease enzyme which functions to hydrolyze protein to amino acids at $\mathrm{pH} 5$ and an optimal temperature of $40{ }^{\circ} \mathrm{C}$.

Variables

Table 1

Total microbes in native chickens aged 2 - 10 weeks were given fermented clove leaf extract through drinking water

\begin{tabular}{lccccc}
\hline \multirow{2}{*}{ Variables } & \multicolumn{4}{c}{ Treatment } & \multirow{2}{*}{ SEM } \\
\cline { 2 - 5 } & P0 & P1 & P2 & P3 & \\
\hline Lactic Acid Bacteria (Log CFU/ml) & $5,41^{\mathrm{c}}$ & $6,89^{\mathrm{a}}$ & $7,07^{\mathrm{a}}$ & $6,38^{\mathrm{b}}$ & 0,17 \\
Escherichia Coli (Log CFU/ml) & $4,79^{\mathrm{a}}$ & $3,73^{\mathrm{b}}$ & $4,03^{\mathrm{ab}}$ & $5,39^{\mathrm{a}}$ & 0,22 \\
Coliform (Log CFU/ml) & $5,53^{\mathrm{a}}$ & $4,64^{\mathrm{b}}$ & $5,20^{\mathrm{ab}}$ & $5,76^{\mathrm{a}}$ & 0,16 \\
Total Plate Count (Log CFU/ml) & $6,01^{\mathrm{b}}$ & $6,36^{\mathrm{b}}$ & $7,21^{\mathrm{a}}$ & $6,17^{\mathrm{b}}$ & 0,19 \\
\hline
\end{tabular}

Information:

1) Values with the same letter on the same row indicate insignificant differences $(P>0.05)$ while values with different letters on the same row indicate significant differences $(\mathrm{P}<0.05)$.

2) P0: drinking water without fermented clove leaf extract P1: drinking water was given $1 \%$ fermented clove leaf extract P2: drinking water was given $2 \%$ fermented clove leaf extract P3: drinking water was given $3 \%$ fermented clove leaf extract

3) SEM: Standard Error Of The Treatment Means 
The total pathogenic bacteria Escherichia Coli and Coliform obtained P1 treatment with 1\% fermented clove leaf extract to get the lowest total pathogenic bacteria. This can be proven that the phytochemical compounds in fermented clove leaves can suppress pathogenic microbes and increase lactic acid bacteria, thereby increasing the performance of native chickens, can be seen in (Table 3), according to the opinion of Natsir et al. (2016), which states that plants that contain phytochemicals as a natural antibiotic with the ability to suppress pathogenic microbes, provide immunity and endurance and improve the appearance of production. According to Brisbin et al. (2008), reduced pathogenic bacteria in the digestive tract of chickens can improve feed digestibility, optimize absorption of nutrients, and increase useful bacteria for chickens.

The results of the study using fermented clove leaf extract showed a significant effect $(\mathrm{P}<0.05)$ on the total plate count (TPC). P2 treatment produced the highest total microbe with $7.21 \mathrm{log} \mathrm{cfu} / \mathrm{ml}$, it can be seen that the total LAB in P2 treatment increased (Table 1) and decreased pathogenic bacteria when compared to treatment P0. Treatment of P0 without giving fermented clove leaf extract obtained the lowest total bacteria followed by low total LAB, thus identifying that giving fermented clove leaf extract was able to increase total microbial growth (TPC) and lactic acid bacteria and reduce pathogenic bacteria (Escherichia Coli and Coliform). This is in line with the statement of Yang et al. (2009), which states that antibiotics in feed can improve the health and performance of poultry by reducing the potential for pathogenic bacteria to increase the growth of beneficial bacteria.

Table 2

Digestibility of native chickens aged 2-10 weeks given fermented clove leaf extract through drinking water

\begin{tabular}{lrrrrr}
\hline \multirow{2}{*}{ Variables } & \multicolumn{4}{c}{ Treatment 2 P } & \multirow{2}{*}{ SEM$^{2}$ ) } \\
\cline { 2 - 5 } & \multicolumn{1}{c}{ P0 } & \multicolumn{1}{c}{ P1 } & P2 & \multicolumn{1}{c}{ P3 } & \\
\hline Dry Matter Digestibility (\%) & $77,93^{\mathrm{bc} 1)}$ & $81,62^{\mathrm{a}}$ & $81,44^{\mathrm{a}}$ & $78,59^{\mathrm{b}}$ & 0,83 \\
Organic Matter Digestibility (\%) & $81,86^{\mathrm{bc}}$ & $85,06^{\mathrm{a}}$ & $84,74^{\mathrm{a}}$ & $82,29^{\mathrm{b}}$ & 0,62 \\
Protein Digestibility (\%) & $86,40^{\mathrm{b}}$ & $88,71^{\mathrm{a}}$ & $85,70^{\mathrm{bc}}$ & $83,42^{\mathrm{d}}$ & 0,64 \\
Digestible Energy (Kcal/h) & $253,41^{\mathrm{b}}$ & $283,55^{\mathrm{a}}$ & $274,67^{\mathrm{a}}$ & $264,23^{\mathrm{ab}}$ & 6,75 \\
\hline
\end{tabular}

Information:

1) Values with the same letter on the same row indicate insignificant differences $(P>0.05)$ while values with different letters on the same row indicate significant differences $(\mathrm{P}<0.05)$.

2) P0: drinking water without fermented clove leaf extract

P1: drinking water was given $1 \%$ fermented clove leaf extract

P2: drinking water was given $2 \%$ fermented clove leaf extract

P3: drinking water was given $3 \%$ fermented clove leaf extract

3) SEM: Standard Error Of The Treatment Means

The dry matter and organic matter digestibility values in the P1 treatment were significantly different (P $<0.05)$ compared to the control. According to Sitepu et al. (2012), the higher the dry matter digestibility value of the ration illustrates that the quality is good so that it is easily digested by the body. The dry matter digestibility values in this study ranged from 77.93 to $81.62 \%$ higher than the results obtained by Abun et al. (2007), which were around 72.07-75.43\%. The increase in the digestibility of organic matter in the P1 treatment was due to the high organic matter content of the ration, around $91.54 \%$, and the high ration consumption (Table 3) so that the digestibility of organic matter was also high. According to Widodo et al. (2015), that the main nutrients needed by LAB are carbohydrates and nitrogen by using them as an energy source. The presence of compounds in clove leaves containing eugenol, saponins, flavonoids, tannins and essential oils (Nurdjannah, 2004) and probiotics in the digestive tract can have a positive effect, thereby increasing the efficiency of using rations (Mulyono \& Wahyono, 2009).

The results of the study on crude protein digestibility showed that P1 treatment had the highest protein digestibility, namely $88.71 \%$, and the lowest in P3 treatment (83.42\%) can be seen in (Table 2). The level of protein digestibility depends on the protein content of feed ingredients and the amount of protein that enters the digestive tract (Tillman et al. 1998). Wahju (2004), stated that the digestibility of poultry protein ranged from $70-85 \%$, Crude protein digestibility in this study ranged from $83.42 \%-88.71 \%$, higher than the results

Bulu, S., Mahardika, I. G., \& Nuriyasa, I. M. (2020). Giving the extract of clove leaves (Syzygium aromaticum L.) fermented through drinking water against growth of kampong chicken. International Journal of Life Sciences, 4(3), 50-58. https://doi.org/10.29332/ijls.v4n3.538 
obtained by Fitasari et al. (2016), around 64, 31 - 72.13\%. Treatment P3 got lower crude protein digestibility than control (significantly different) even though the rations were given with the same composition. This can be because fermented clove leaf extract has a high enough tannin content so that when the $3 \%$ administration experiences a significant decrease in crude protein digestibility compared to P1 with 1\% fermented clove leaf extract which can provide higher protein digestibility. It can be seen that tannins are anti-nutritional compounds because of their ability to form complexes with proteins found in the feed so that these proteins cannot be digested (Magdalena et al., 2014). Administration of tannins in low levels can increase the efficiency of microbes in the gut, have an antioxidant effect, and can protect healthy cells against toxic substances. The decrease in pathogenic bacteria such as Escherichia coli and Coliform in the digestive tract will cause probiotic bacteria such as Lactobacillus sp to increase so that their efficiency in the absorption of nutrients increases (Bidura, 2007).

The results of research on digestible energy (DE) showed that treatment P1 and P2 showed significantly different $(\mathrm{P}<0.05$ ) with treatment P0 (Table 2). Provision of fermented clove leaf extract at the $1 \%$ and $2 \%$ levels of digestible energy was better than the control. It can be seen that the high ration energy content and high ration consumption as well as the important role of phenolic compounds such as alkaloids, steroids, terpenoids, phenolics, saponins, flavonoids, and tannins, which is given in the right dose will get good results. This bioactive has an antibacterial, antioxidant, and anti-fungal activity which can improve digestive tract function (Edi et al., 2018). The feed consumed by livestock will affect the level of consumption, feed digestibility, body weight gain, sex maturity, egg production, and egg quality (Irawan et al., 2012; Suryani et al., 2017). According to Wahju (2004), it is inversely proportional to the amount of energy in feed, consumption increases if the amount of energy in feed is less than demand and consumption will decrease if the amount of feed energy exceeds demand.

Based on statistical analysis, giving fermented clove leaf extract through drinking water as much as $1 \%$ (P1) significantly $(\mathrm{P}<0.05)$ increased the final body weight and weight gain of native chickens aged 2-10 weeks compared to the control treatment P0, P2, and P3 (Table 3). The final body weight is influenced by the amount of feed consumed and the nutrient content consumed. Ariesta et al. (2015), stated that the nutrient content which is more absorbed by the body of the chicken will provide a higher final body weight because it will increase tissue development in increasing livestock body weight. In this study, the digestibility of dry matter, digestibility of organic matter, digestibility of protein, and digestible energy in treatment P1 was higher than treatment P0, P2, and P3 in (Table 2), so that the nutrients absorbed by the native chickens were higher and caused the final body weight and higher body weight than treatment P0, P2, and P3. Mahardika et al. (2013), states that protein balance includes protein consumption, protein lost in feces, undigested protein, and protein retained in the body. Further explained this shows that chickens that receive feed with higher energy and protein content will have better growth.

The results of statistical analysis on the treatment of ration consumption showed insignificant differences $(\mathrm{P}>0.05)$. This is because the nutritional content of native chicken rations given is the same in each treatment. Ration consumption is influenced by the size and breed of chickens, environmental temperature, the ration system, livestock health, sex, livestock activity, and the quality of the rations given (Rasyaf, 2006; Short et al., 1996; Kim \& Holtzapple, 2006). Provision of rations with the same iso protein and iso energy nutritional content will cause the level of ration consumption to be relatively the same (not significantly different). The presence of phytochemical compounds in clove leaves, so that with the addition of fermented clove leaf extract, it can balance the intestinal microflora, optimize the digestive tract, and improve feed digestibility. The ration consumption for Kampung Unggul Balitnak (KUB) chickens ranges from 80-85 g/head/day (Sartika, 2016), when compared in this study the ration consumption ranges from $47-50 \mathrm{~g} / \mathrm{head} /$ day it is said that this study is effective in ration consumption better.

Table 3

Growth of native chickens aged 2-10 weeks given fermented clove leaf extract through drinking water

\begin{tabular}{lrrrrr}
\hline \multirow{2}{*}{ Variable } & \multicolumn{3}{c}{ Treatment $^{2)}$} & \multirow{2}{*}{ SEM$^{33}$} \\
\cline { 2 - 4 } & \multicolumn{1}{c}{$\mathrm{P} 0$} & $\mathrm{P} 1$ & $\mathrm{P} 2$ & $\mathrm{P} 3$ & \\
\hline Initial Weight $(\mathrm{g} /$ tail) & $\left.149,60^{\mathrm{a} 1}\right)$ & $151,20^{\mathrm{a}}$ & $150,80^{\mathrm{a}}$ & $149,33^{\mathrm{a}}$ & 1,04 \\
Final Weight $(\mathrm{g} /$ tail) & $936,00^{\mathrm{b}}$ & $1062,93^{\mathrm{a}}$ & $992,00^{\mathrm{b}}$ & $978,67^{\mathrm{b}}$ & 21,87 \\
\hline
\end{tabular}




\begin{tabular}{|c|c|c|c|c|c|}
\hline Weight Gain (g / tail) & $786,40^{\mathrm{b}}$ & $911,73^{\mathrm{a}}$ & $841,20^{\mathrm{b}}$ & $829,33^{\mathrm{b}}$ & 21,76 \\
\hline Ration Consumption (g / tail) & $2658,87 a$ & $2779,80^{a}$ & $2722,47 \mathrm{a}$ & $2635,93^{a}$ & 40,83 \\
\hline Drinking Water Consumption (ml / tail) & $5162,87 a$ & $4827,60^{a}$ & $4477,40^{\mathrm{b}}$ & $4192,73^{b c}$ & 166,02 \\
\hline Feed Conversion Ratio (FCR) & $3,39^{a}$ & $3,06^{\mathrm{cd}}$ & $3,24^{\mathrm{b}}$ & $3,18^{\mathrm{bc}}$ & 0,05 \\
\hline
\end{tabular}

Information:

1) Values with the same letter on the same row indicate insignificant differences $(P>0.05)$ while values with different letters on the same row indicate significant differences $(\mathrm{P}<0.05)$.

2) P0: drinking water without fermented clove leaf extract

P1: drinking water was given $1 \%$ fermented clove leaf extract

P2: drinking water was given $2 \%$ fermented clove leaf extract

P3: drinking water was given $3 \%$ fermented clove leaf extract

3) SEM: Standard Error Of The Treatment Means

Based on a statistical analysis of drinking water consumption given fermented clove leaf extract through drinking water showed a significant difference $(\mathrm{P}<0.05)$. The highest drinking water consumption was in treatment P0 (0\%) and the lowest drinking water consumption was in treatment P3 $(3 \%)$. This is because the levels of tannins in fermented clove leaf extract are still high even though the fermentation process has been carried out. Tannins have a bitter/bitter taste so that drinking water consumption at $2 \%$ and $3 \%$ fermented clove leaf extract decreased and was significantly different $(P<0.05)$ with the control. Wahju $(2004)$, chicken has taste buds but has a limited ability to distinguish odors. Tannins are astringents, polyphenols, have a bitter taste, can bind and precipitate protein, and are water-soluble. According to the opinion of Scott et al. (1969), many factors can increase and decrease drinking water consumption, including: smell, taste, aroma, and additives used.

The lowest FCR value in treatment P1 with (1\%) giving fermented clove leaf extract and the highest in treatment $\mathrm{P} 0$ as control was significantly different $(\mathrm{P}<0.05)$ (Table 3). The smaller the ratio conversion rate, the better the chicken is in converting the feed to meat and the nutrition of the ratio can be said to be good (Wahju, 2004). Provision of fermented clove leaf extract through drinking water can improve ration efficiency because active compounds can help metabolize food substances so that food substances can be digested and absorbed better, marked by an increase in body weight gain. Super free-range chickens (aged 3 - 10 weeks) with the provision of adlibitum rations have a ration conversion value of 5.0 - 5.5 (Wicaksono, 2015). The ration conversion in this study aged 2-10 weeks was better, namely $3.06-3.39$. Low FCR is due to increased feed digestibility because fermented clove leaf extract contains bioactive flavonoids and antioxidants. After all, these bioactive have an antibacterial, antioxidant, anti-fungal activity that can improve digestive tract function (Edi et al., 2018).

\section{Conclusion}

Provision of fermented clove leaf extract 1 - 2\% through drinking water can increase lactic acid bacteria and reduce pathogenic bacteria, increase feed digestibility, thereby increasing the growth of native chickens aged 2-10 weeks.

Acknowledgments

We are grateful to two anonymous reviewers for their valuable comments on the earlier version of this paper.

Bulu, S., Mahardika, I. G., \& Nuriyasa, I. M. (2020). Giving the extract of clove leaves (Syzygium aromaticum L.) fermented through drinking water against growth of kampong chicken. International Journal of Life Sciences, 4(3), 50-58. https://doi.org/10.29332/ijls.v4n3.538 


\section{References}

Ariesta, A. H., Mahardika, I. G., \& Dewi, G. A. M. K. (2015). Pengaruh level energi dan protein ransum terhadap penampilan ayam kampung umur 0-10 minggu. Majalah Ilmiah Peternakan, 18(3), 164260.

Arifin, S. (2003). Pengaruh Penggunaan Bekatul Fermentasi dengan EM4 (Efektif Mikroorganisme) dalam Ransum terhadap Efisiensi Pakan dan Income Over Feed Cost (Iofc) pada Ayam Potong (Broiler). Departement of Animal Husbandry. Universitas Muhammadiyah Malang, 1.

Bidura, I. G. N. G. (2007). Aplikasi Produk Bioteknologi Pakan Ternak. Universitas Udayana, Denpasar.

Brisbin, J. T., Gong, J., Lusty, C. A., Sabour, P., Sanei, B., Han, Y., ... \& Sharif, S. (2008). Influence of in-feed virginiamycin on the systemic and mucosal antibody response of chickens. Poultry science, 87(10), 19951999. https://doi.org/10.3382/ps.2008-00159

Bukar, A., Uba, A., \& Oyeyi, T. (2010). Antimicrobial profile of Moringa oleifera Lam. extracts against some food-borne microorganisms. Bayero Journal of Pure and Applied Sciences, 3(1).

Dubey, J. P., Sundar, N., Gennari, S. M., Minervino, A. H. H., Farias, N. D. R., Ruas, J. L., ... \& Su, C. (2007). Biologic and genetic comparison of Toxoplasma gondii isolates in free-range chickens from the northern Para state and the southern state Rio Grande do Sul, Brazil revealed highly diverse and distinct parasite populations. Veterinary parasitology, 143(2), 182-188. https://doi.org/10.1016/j.vetpar.2006.08.024

Edi, D. N., Natsir, M. H., \& Djunaidi, I. (2018). Pengaruh penambahan ekstrak daun jati (tectona grandis linn. F) dalam pakan terhadap performa ayam petelur. Jurnal Nutrisi Ternak Tropis, 1(1), 34-44.

Ferdinanti, E. (2001). Uji aktivitas antibakteri obat kumur minyak cengkeh (Syzygium aromaticum (L) Merr \& Perry) asal bunga, tangkai bunga, dan daun cengkeh terhadap bakteri. Skripsi, Institut Sains dan Teknologi Nasional.

Fitasari, E., Reo, K., \& Niswi, N. (2016). Penggunaan kadar protein berbeda pada ayam kampung terhadap penampilan produksi dan kecernaan protein. Jurnal Ilmu-Ilmu Peternakan, 26(2), 73-83.

Heinrich, M., Barnes, J., Gibbons, S., \& Williamson, E. M. (2010). Farmakognosi dan Fitoterapi (Fundamentals of Pharmacognosy and Phytotherapy).

Huang, C. C., Zeng, Y. H., Luo, X. J., Tang, B., Liu, Y. E., Ren, Z. H., \& Mai, B. X. (2018). Level changes and human dietary exposure assessment of halogenated flame retardant levels in free-range chicken eggs: a case study of a former e-waste recycling site, South China. Science of the Total Environment, 634, 509-515. https://doi.org/10.1016/j.scitotenv.2018.03.386

Irawan, I., Sunarti, D., \& Mahfudz, L. D. (2012). Pengaruh Pemberian Pakan Bebas Pilih terhadap Kecernaan Protein Burung Puyuh. Animal Agriculture Journal, 1(2), 238-245.

Jufri, M. (2010). Pengaruh Pemberian Serbuk Cengkeh (Syzygium aromaticum) pada Ransum Terhadap Performans Ayam Ras Pedaging (Broiler) (Doctoral dissertation, Universitas Islam Negeri Alauddin Makassar).

Khera, N. E. H. A., \& Bhargava, S. A. N. G. E. E. T. A. (2013). Phytochemical and pharmacological evaluation of Tectona grandis Linn. Int J Pharm Pharm Sci, 5(3), 923-927.

Kim, S., \& Holtzapple, M. T. (2006). Effect of structural features on enzyme digestibility of corn stover. Bioresource technology, 97(4), 583-591. https://doi.org/10.1016/j.biortech.2005.03.040

Kogoya, D., Mandey, J. S., Rumokoy, L. J., \& Regar, M. N. (2019). Penambahan daun gedi (Abelmoschus Manihot (L) Medik) sebagai "Additive" dalam air minum dan pengaruhnya terhadap performans ayam kampung super. Zootec, 39(1), 82-92.

Magdalena, S., Natadiputri, G. H., Nailufar, F., \& Purwadaria, T. (2014). Utilization of Natural Products as Functional Feed. Indonesian Bulletin of Animal and Veterinary Sciences, 23(1), 31-40.

Mahardika, I. G., Dewi, G. K., Sumadi, I. K., \& Suasta, I. M. (2013). Kebutuhan energi dan protein untuk hidup pokok dan pertumbuhan pada ayam kampung umur 10-20 minggu. Majalah ilmiah peternakan.

Mulyono, R. M., \& Wahyono, F. (2009). Kajian penggunaan probiotik saccharomyces cereviseae sebagai alternatif aditif antibiotik terhadap kegunaan protein dan energi pada ayam broiler. J. Indon. Trop. Anim. Agri, 34(2), 145-151.

Natsir, M. H. (2016). Penggunaan Kombinasi Kunyit (Curcuma domestica) Dan Jahe (Zingiber officinale) Bentuk Enkapsulasi Dan Tanpa Enkapsulasi Terhadap Karakteristik Usus Dan Mikroflora Usus Ayam Pedaging. Buletin Peternakan, 40(1), 1-10.

Nurjanah, N. (2004). Diversifikasi Penggunaan Cengkeh. Balai Besar Penelitian dan Pengembangan Pasca Panen Pertanian, Bogor. 
Rasyaf, M. (2006). Manajemen Peternakan Ayam. Swadaya, Jakarta.

Rusmana, D., \& Saefulhadjar, D. (2007). Efek Pengolahan Limbah Sayuran Secara Mekanis Terhadap Nilai Kecernaan pada Ayam Kampung Super JJ-101. Jurnal Ilmu Ternak Universitas Padjadjaran, 7(2).

Sartika, T. (2016). Panen ayam Kampung 70 hari. Penebar Swadaya Grup.

Scott, M. L., Nesheim, M. C., \& Young, R. J. (1969). Nutrition of the Chicken. Nutrition of the chicken.

Short, F. J., Gorton, P., Wiseman, J., \& Boorman, K. N. (1996). Determination of titanium dioxide added as an inert marker in chicken digestibility studies. Animal feed science and technology, 59(4), 215-221. https://doi.org/10.1016/0377-8401(95)00916-7

Sitepu, S. R., \& Supratman, H. (2012). PengaruhImbanganEnergidan Protein RansumterhadapKecernaanBahanKeringdan Protein KasarpadaAyam Broiler. Students e-Journal, 1(1), 15.

Steel, R. G. D. dan JH Torrie. 1993. Prinsip dan Prosedur Statistika. Suatu Pendekatan Biometrik. Edisi, 2.

Sumardi, S., \& Lengkana, D. (2009). Isolasi Bacillus penghasil protease dari saluran pencernaan ayam kampung. In Proseeding Seminar Hasil Penelitian \& Pengabdian Kepada Masyarakat, Unila, 2009 (pp. A164). Lembaga Penelitian Universitas Lampung.

Suryani, N. N., Suarna, I. W., Sarini, N. P., \& Mahardika, I. G. (2017). Increasing energy ration of Bali cattle to improve digestible nutrient, milk yield and milk quality. International research journal of engineering, IT \& scientific research, 3(1), 8-17.

Tillman, A. D., Hartadi, H., Reksohadiprodjo, S., Prawirokusumo, S., \& Lebdosoekojo, S. (1998). Ilmu makanan ternak dasar.

Wahju, J. (2004). Ilmu Nutrisi Unggas. Edisi ke-4. Universitas Gadjah Mada Press, Yogyakarta.

Wang, K. H., Shi, S. R., Dou, T. C., \& Sun, H. J. (2009). Effect of a free-range raising system on growth performance, carcass yield, and meat quality of slow-growing chicken. Poultry science, 88(10), 2219-2223. https://doi.org/10.3382/ps.2008-00423

Wicaksono, D. (2015). Perbandingan Fertilitas, Susut Tetas, Daya Tetas, dan Bobot Tetas Ayam Kampung pada Peternakan Kombinasi. Skripsi. Jurusan Peternakan. Universitas Lampung.

Widodo, T. S., Sulistiyanto, B., \& Utama, C. S. (2015). Jumlah bakteri asam laktat (BAL) dalam digesta usus halus dan sekum ayam broiler yang diberi pakan ceceran pabrik pakan yang difermentasi. Jurnal Agripet, 15(2), 98-103.

Yaman, I. M. A. (2013). Ayam Kampung Pedaging Unggul. Penebar Swadaya Grup.

Yang, Y., Iji, P. A., \& Choct, M. (2009). Dietary modulation of gut microflora in broiler chickens: a review of the role of six kinds of alternatives to in-feed antibiotics. World's Poultry Science Journal, 65(1), 97-114.

Zainuddin, D. 2006. Tanaman obat meningkatkan efisiensi pakan dan kesehatan ternak unggas. Proc. Lokakarya Nasional Inovasi Teknologi dalam Mendukung Usaha Ternak Unggas Berdaya saing. Agustus 2006. Undip. Semarang bekerjasama dengan Puslitbang Peternakan Bogor.

Bulu, S., Mahardika, I. G., \& Nuriyasa, I. M. (2020). Giving the extract of clove leaves (Syzygium aromaticum L.) fermented through drinking water against growth of kampong chicken. International Journal of Life Sciences, 4(3), 50-58. https://doi.org/10.29332/ijls.v4n3.538 


\section{Biography of Authors}

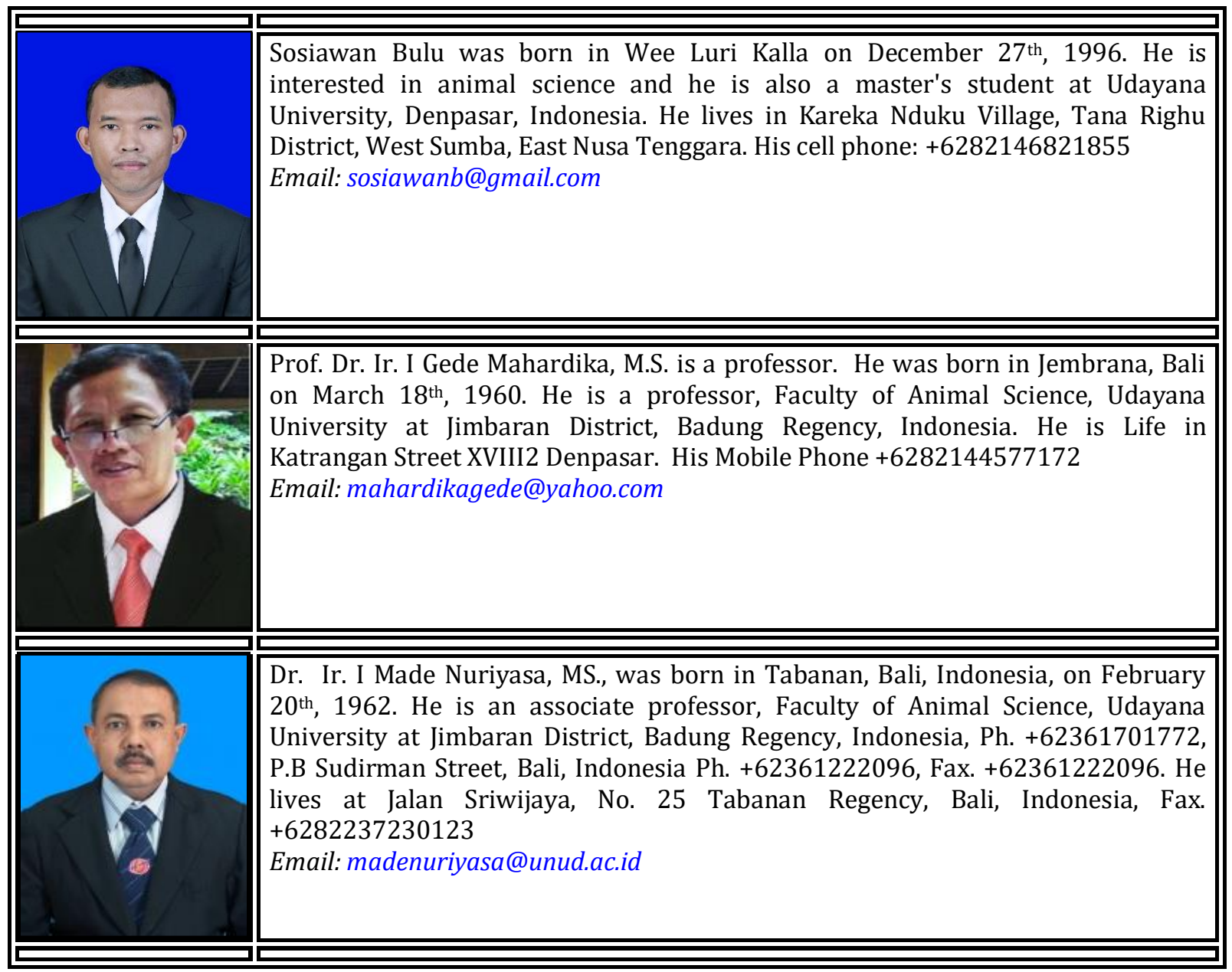

